\title{
Letter of Credit (L/C) Sebagai Cara Pembayaran yang Paling Aman dalam Transaksi Pembayaran Perdagangan Internasional/Ekspor-Impor. (Studi Kasus pada PT. San San Saudaratex Jaya).
}

\section{Agus Dedi Subagja}

Department of Business Administration, Faculty of Social and political Sciences, Universitas Padjadjaran (UNPAD).

ads_fileinc@yahoo.co.id
E-ISSN (2721-0642)

Recieved:

March 262020

Revised:

April 102020

Accepted:

April 132020

Doi Number

10.37950/ijd.v2i1.38

\section{Abstract}

International trade is a trade between two companies with different countries, place, social, economic conditions involving those conditions, there are problems arise is the method of payments in that trade. The purpose of this observation is to explain the process of using the Letter of Credit that was used by PT. San San Saudaratex Jaya, ascertaining this Letter of Credit in export and import. Letter of Credit is one of the international paying methods, that the safest against to the exporter or importer. The observation method that was used by the writer to collect data and information is field research, observation and whereas, the descriptive method was used to analyze the data. The result of this observation, are PT. San San Saudaratex Jaya, uses a Letter of Credit as a method of payment in export and import. There are L/C type Sight and Usance, and also Transferable L/C for the other beneficiary. The company chooses that kind of $\mathrm{L} / \mathrm{C}$ because there is better for both sides the exporter and the importer. The problems are facing by the company are discrepancies, bank fees in relation to the documents in using L/C. It is better if the company using another method of payments base on relation and trust among importer and exporter in doing the business for deducting expenses in relation to L/C documents, that so expansive.

Keywords: letter of credit, international trade, implementation 
Volume 2 Issue 1, April 2020

http://hk-publishing.id/ijd-demos

\begin{abstract}
Abstrak
Perdagangan internasional adalah perdagangan yang melibatkan dua pengusaha dengan tempat, sosial budaya, kondisi ekonomi yang berbeda dengan melihat hal tersebut maka ada masalah yang timbul yaitu cara penyelesaian pembayaran yang sering menjadi masalah. Tujuan dari penelitian ini adalah untuk mengetahui dan menjelaskan bagaimana proses pelaksanaan penggunaan Letter of Credit (L/C) dalam transaksi ekspor dan impor yang telah dilakukan oleh PT. San San Saudaratex Jaya. Letter of Credit merupakan salah satu cara pembayaran didalam perdagangan internasional yang paling aman ditinjau dari sudut eksportir maupun importir. Metode penelitian yang digunakan penulis untuk mengumpulkan data dan informasi yaitu penelitian lapangan berupa observasi dan wawancara, serta penelitian pustaka. Sedangkan untuk menganalisa data, metode yang digunakan yaitu metode deskriptif. Hasil yang diperoleh dalam penelitian ini, antara lain; PT. San San Saudaratex Jaya, menggunakan L/C dalam transaksi ekspor dan impor. Dalam hal ini perusahaan menggunakan L/C dengan cara pembayaran Sight dan Usance, sedangkan kemungkinan penggunaannya oleh Beneficiary lain digunakan Transferable L/C. Perusahaan memilih jenis-jenis L/C tersebut, karena dianggap menguntungkan ditinjau dari segi eksportir maupun importir. Hambatan-hambatan yang berupa discrepancies, pembayaran biaya bank, didalam pengurusan dokumen merupakan salah satu hambatan didalam penggunaan L/C. Akan lebih baik lagi jika perusahaan menggunakan metode pembayaran internasional yang lainnya, tentunya sesuai dengan kesepakatan kedua belah pihak untuk menekan biaya-biaya yang timbul didalam penggunaan L/C, yang dirasakan cukup besar.
\end{abstract}

Kata kunci: letter of credit, Perdagangan Internasional, implementasi

\title{
Pendahuluan
}

Transaksi perdagangan luar negeri yang lebih dikenal dengan istilah eksporimpor pada hakikatnya adalah suatu transaksi yang sederhana dan tidak lebih dari membeli dan menjual barang antara pengusaha-pengusaha yang bertempat di negara-negara yang berbeda. Berkaitan dengan fenomena tersebut maka ada hal menarik yang dapat dikaji, yaitu mengenai cara penjualan dan pembayaran produk yang seringkali menjadi sumber permasalahan. Sebagai contoh dalam perdagangan internasional, penjual dan pembeli mempunyai latar belakang lingkungan yang berbeda dari segi politik, ekonomi, sosial, budaya, dan lain sebagainya. Oleh karena itu masing-masing pihak mempunyai kekhawatiran bahwa pihak lawan dagangnya tidak melaksanakan kewajibannya sesuai dengan yang disepakati dan tentunya setiap kemungkinan tersebut merupakan resiko bagi masing-masing pihak. Resikoresiko tersebut berkaitan dengan penyerahan barang oleh penjual kepada pembeli dan pembayaran harga barang oleh pembeli kepada penjual, kapan dan bagaimana cara penyerahan barang dan pembayaran tersebut sebaiknya dilakukan, sehingga masing-masing pihak merasa aman, tergantung kepada hubungan dan kepercayaan 
kedua belah pihak. Oleh karena itu didalam perdagangan internasional terdapat beberapa metode pembayaran.

Tabel 1 Perbandingan beberapa metode pembayaran

\begin{tabular}{|c|c|c|c|c|}
\hline Metode & Pembayaran & $\begin{array}{c}\text { Barang } \\
\text { diperoleh } \\
\text { pembeli }\end{array}$ & $\begin{array}{l}\text { Resiko Bagi } \\
\text { Eksportir }\end{array}$ & $\begin{array}{l}\text { Resiko Bagi } \\
\text { Importir }\end{array}$ \\
\hline $\begin{array}{c}\text { Advanced } \\
\text { Payment/ } \\
\text { Pembayaran } \\
\text { di muka }\end{array}$ & $\begin{array}{c}\text { Sebelum } \\
\text { pengiriman }\end{array}$ & $\begin{array}{c}\text { Sesudah } \\
\text { pembayaran }\end{array}$ & Tidak ada & $\begin{array}{l}\text { Tergantung pada } \\
\text { eksportir dalam } \\
\text { mengirimkan } \\
\text { barang sesuai } \\
\text { dengan yang di } \\
\text { pesan. }\end{array}$ \\
\hline $\begin{array}{c}\text { Letter of } \\
\text { Credit }\end{array}$ & $\begin{array}{c}\text { Apabila } \\
\text { barang } \\
\text { dikirim dan } \\
\text { dokumen } \\
\text { sesuai } \\
\text { dengan L/C }\end{array}$ & $\begin{array}{c}\text { Sesudah } \\
\text { pembayaran }\end{array}$ & $\begin{array}{l}\text { Sedikit atau } \\
\text { tergantung } \\
\text { pada jenis } \\
\text { L/C dan } \\
\text { contoh barang }\end{array}$ & $\begin{array}{l}\text { Tergantung pada } \\
\text { eksportir dalam } \\
\text { mengirimkan } \\
\text { barang sesuai } \\
\text { dengan yang } \\
\text { diungkapkan } \\
\text { dalam dokumen. }\end{array}$ \\
\hline $\begin{array}{c}\text { Collection } \\
\text { Draft/ } \\
\text { Wesel } \\
\text { Inkaso }\end{array}$ & $\begin{array}{c}\text { Saat } \\
\text { penyerahan } \\
\text { draft kepada } \\
\text { pembeli }\end{array}$ & $\begin{array}{c}\text { Sesudah } \\
\text { pembayaran }\end{array}$ & $\begin{array}{c}\text { Pembeli dapat } \\
\text { menolak } \\
\text { barang yang } \\
\text { dikirim }\end{array}$ & $\begin{array}{c}\text { Sama seperti L/C } \\
\text { kecuali bila } \\
\text { importir bisa } \\
\text { memeriksa barang } \\
\text { sebelum } \\
\text { pembayaran. }\end{array}$ \\
\hline $\begin{array}{l}\text { Time Draft/ } \\
\text { Document } \\
\text { Against } \\
\text { Acceptance }\end{array}$ & $\begin{array}{c}\text { Saat jauh } \\
\text { temponya } \\
\text { draft }\end{array}$ & $\begin{array}{c}\text { Sebelum } \\
\text { pembayaran }\end{array}$ & $\begin{array}{c}\text { Tergantung } \\
\text { pada pembeli } \\
\text { dalam } \\
\text { membayar } \\
\text { draft }\end{array}$ & $\begin{array}{c}\text { Sama seperti } \\
\text { diatas }\end{array}$ \\
\hline $\begin{array}{c}\text { Open } \\
\text { Account/ } \\
\text { Pembayaran } \\
\text { dibelakang }\end{array}$ & $\begin{array}{c}\text { Sesuai } \\
\text { dengan } \\
\text { kesepakatan }\end{array}$ & $\begin{array}{c}\text { Sebelum } \\
\text { pembayaran }\end{array}$ & $\begin{array}{c}\text { Sangat } \\
\text { tergantung } \\
\text { pada pembeli }\end{array}$ & Tidak ada \\
\hline $\begin{array}{c}\text { Consignment/ } \\
\text { Konsingasi }\end{array}$ & $\begin{array}{c}\text { Sesudah } \\
\text { barang laku } \\
\text { dijual }\end{array}$ & $\begin{array}{c}\text { Sebelum } \\
\text { pembayaran }\end{array}$ & $\begin{array}{c}\text { Resiko barang } \\
\text { tidak laku } \\
\text { terjual dan } \\
\text { sangat } \\
\text { tergantung } \\
\text { pada pembeli } \\
\text { dalam } \\
\text { membayar } \\
\text { kewajibannya }\end{array}$ & Tidak ada \\
\hline
\end{tabular}


Sumber: Perbandingan beberapa metode pembayaran, Teguh B dan Fandy C. Pemasaran Internasional. Yogyakarta: BPFE, 1997, h. 163. (ditambah).

Letter of Credit merupakan sistem pembayaran yang paling aman di pandang dari sudut kepentingan eksportir maupun importir, merupakan suatu sarana pembayaran yang paling efektif yang ditawarkan oleh bank-bank devisa, dalam penyelesaian pembayaran transaksi bisnis internasional.

\section{Kerangka Teori}

Untuk menunjang kemudahan perdagangan internasional, khususnya transaksi ekspor dan impor, digunakan Letter of Credit (L/C) sebagai sarana pembiayaan transaksi sehingga dengan adanya pembukaan L/C maka pihak importir harus menyediakan dana untuk membayar harga barang yang diimpor kepada eksportir. Di pihak lain eksportir harus menyediakan barang yang dimaksud. Di dalam transaksi tersebut di atas timbul suatu kewajiban untuk melakukan pembayaran dalam valuta asing sehingga terjadilah kegiatan transaksi devisa antara dua jenis mata uang yang berbeda. Transaksi ekspor dan impor dapat mengakibatkan diterbitkannya dokumen-dokumen bukti pengiriman pengapalan barang yang diekspor. Demikian pula dokumen bukti kepemilikan atas barang yang diimpor.

\section{Pengertian Letter of Credit}

Pengertian Letter of Credit (L/C) menurut Roselyne Hutabarat (1996: 25) adalah : "Sebuah instrumen yang dikeluarkan oleh sebuah bank atas nama salah satu nasabahnya, yang menugaskan seorang atau sebuah perusahaan penerima instrumen tersebut menarik wesel atas bank yang bersangkutan atau salah satu bank korespondennya bagi kepentingannya, berdasarkan kondisi-kondisi atau persyaratan-persyaratan yang tercantum pada instrumen tersebut".

Definisi lain mengenai L/C dalam arti luas menurut Roselyne Hutabarat adalah: "Suatu pernyataan yang dikeluarkan oleh suatu bank untuk mempertaruhkan kredit (tingkat kepercayaan) akan dirinya yang telah cukup dikenal baik, sebagai pengganti kredit terhadap importir tersebut, yang mungkin baik juga tetapi tidak begitu dikenal". Dalam kamus Webster (1993: 1298) L/C adalah: "Letter addressed by a banker to a correspondent certifying that a person named therein is entitled to draw on him or his credit up to a certaim sum".

Ensiklopedi Ekonomi, Bisnis dan Manajemen (1992: 360): “L/C dalam bahasa Indonesia sering disebut surat kredit berdokumen, adalah alat pembayaran yang dikeluarkan oleh bank atas permintaan pembeli dalam transaksi dagang internasional (ekspor-impor)".

Sedangkan menurut Amir MS (1996: 37) Lettter of Credit adalah: "Suatu surat yang dikeluarkan oleh suatu bank atas permintaan importir langganan bank tersebut yang ditujukan kepada eksportir di luar negeri yang menjadi relasi importir itu, yang memberi hak kepada eksportir itu untuk menarik wesel-wesel atas importir bersangkutan untuk sejumlah uang yang disebutkan dalam surat itu. Seterusnya bank bersangkutan menjamin untuk mengakseptir atau menghonorir wesel yang ditarik itu asal saja sesuai dan memenuhi semua syarat yang tercantum dalam surat itu". 
Beberapa pengertian tersebut diatas mengandung pengertian dan tujuan yang sama, dan dapatlah disimpulkan bahwa L/C tersebut merupakan surat yang dikeluarkan oleh bank (opening bank) atas permintaan pembeli (importir) melalui bank koresponden sebagai suatu jaminan dari pembeli kepada penjual atas pembayaran terhadap sejumlah barang yang dikirimkannya kepada pembeli.

\section{Tujuan dan Fungsi L/C}

Letter of Credit pada umumnya cenderung ditujukan untuk kepentingan eksportir dan sebagai akibatnya eksportir akan mendesak importir agar menerbitkan L/C guna kepentingannya sebelum pengapalan barang terjadi.

Beberapa kebaikan Letter of Credit $(L / C)$ yaitu:

- Penjual/eksportir dapat lebih menggantungkan kepercayaan pada L/C yang dikeluarkan bank dank arena itu yang bersangkutan merasa terjamin akan pembayaran setelah adanya penyerahan-penyerahan dokumen-dokumen yang sesuai dengan syarat-syarat L/C.

- Penjual/eksportir menerima pembayaran segera dari bank pembayar bilamana semua dokumen yang sesuai dengan syarat L/C diserahkan pada bank pembayar walaupun pembeli/importir belum menerima dokumendokumen tersebut.

- Penjual/eksportir dapat menggunakan L/C untuk pembiayaan selanjutnya seperti Back to Back L/C dan sebagainya.

- Pembeli/importir biasanya tidak diharuskan menyediakan dana atau kadang-kadang persentase tertentu saja sampai barang impor tiba untuk ditebus.

- Pembeli/importir merasa terjamin bahwa banknya akan menolak pembayaran kepada penjual kecuali penjual telah memenuhi persyaratanpersyaratan L/C yang telah diminta oleh importir kepada banknya seperti yang ditentukan dalam $\mathrm{L} / \mathrm{C}$.

\section{Hasil dan Diskusi}

Secara garis besar ada empat pihak (party) yang terlibat dalam aktivitas perdagangan dengan menggunakan L/C tersebut yaitu:

Tabel 2 Pihak-pihak yang terlibat dalam L/C

\begin{tabular}{|l|l|l|l|}
\hline 1. Pembeli/Buyer & 2. Penjual/Seller & 3. Buyer Bank & 4. Sellers Bank \\
\hline Applicant & Beneficiary & Issuing & Advising \\
\hline Importer & Exporter & Negotiation & Confirming \\
\hline Account Party & Shipper & Paying & Negotiating \\
\hline Consignee & Consignor & Accepting & Paying \\
\hline
\end{tabular}

1. Pembeli atau Applicant 
Pihak ini mengajukan permohonan pembukaan L/C kepada banknya berdasarkan kontrak penjualan (Sales Contract) atau persetujuan yang telah disepakati bersama pihak penjual. Demikian pula mengenai bank mana yang akan diminta untuk melakukan pembukuan L/C yang dimaksud.

2. Bank Pembuka atau Opening Bank

Suatu bank yang melakukan pembukaan L/C berbuat demikian atas permintaan dan sesuai dengan permintaan nasabahnya (Applicant) oleh karena itu sudah sewajarnya apabila Applicant pada akhirnya harus memikul beban dan resiko yang timbul sebagai konsekuensi instruksi itu. Dengan membuka L/C maka bank yang bersangkutan telah mengikat dirinya atau akan menjamin melakukan pembayaran kepada Beneficiary atas penyerahan dokumen dan sesuai dengan kondisi yang ditetapkan.

3. Bank Penerus atau Advising Bank

Advising Bank haruslah Correspondent Bank dari Issuing Bank yang sudah ada kerjasama sebelumnya dalam banking Arrangement Book, dimana diantara mereka sudah saling tahu tentang test key dan aling menyimpan contoh tanda tangan. Fungsi bank penerus hanyalah meneruskan L/C yang dibuka oleh suatu bank (bank pembuka) kepada Beneficiary. Oleh karena itu keterlibatannya dalam mekanisme L/C tidak menimbulkan tanggung jawab atau kewajiban baru.

4. Bank Negosiasi atau Negotiating Bank

Kebanyakan L/C memungkinkan Beneficiary menjual atau menyerahkan atau menegoisasikan dokumen-dokumennya kepada bank yang ditunjuk dalam $\mathrm{L} / \mathrm{C}$ atau bank pilihannya sendiri. Bank bersedia membeli atau mengambil alih atau menegoisasi dokumen tersebut disebut Bank Penegoisasi. Bank ini bersedia berbuat demikian karena dokumen tersebut dilandasi oleh adanya L/C yang dibuka oleh suatu bank yang sudah dikenal reputasinya dan dokumen yang diambil alihnya itu menurut penilaian sesuai dengan syarat dan kondisi $\mathrm{L} / \mathrm{C}$ yang bersangkutan.

5. Bank Pembayar atau Paying Bank (Restricted L/C)

Paying Bank adalah bank yang menurut penetapan dalam L/C diberi kuasa oleh bank pembuka untuk melakukan pembayaran atas dasar penyerahan dokumen yang menurut penilaiannya sesuai dengan syarat dan kondisi L/C. Kecuali Paying Bank turut meng-confirm L/C atau sebagai bank pembuka, maka penunjukkannya sebagai Paying Bank oleh bank pembuka tidak menimbulkan kewajiban baginya untuk melakukan pembayaran. Bank pembuka menjamin untuk membayar kembali kepada Paying Bank segala pembayar yang telah dilakukan.

6. Bank Pengaksep atau Accepting Bank

Apabila suatu bank atas permintaan bank pembuka telah melakukan akseptasi atas wesel berjangka yang ditarik berdasarkan L/C yang bersangkutan, maka bank tersebut disebut bank pengaksep atau Accepting Bank. Dengan mengaksep wesel itu, Accepting Bank telah mengikatkan diri untuk membayar nominal wesel pada saat jatuh waktunya. Atas jasa yang diberikannya itu, Accepting Bank berhak menerima biaya akseptasi atau Accepting Commision sebesar presentase tertentu dari nominal wesel.

7. Bank Penjamin atau Confirming Bank 
Adakalanya sebuah L/C dianggap belum cukup meyakinkan Beneficitary akan pelaksanaan jaminan yang diberikan. Hal ini antara lain disebabkan oleh belum begitu dikenalnya bonafiditas atau reputasi bank pembuka L/C yang bersangkutan. Berhubungan dnegan itu diperlukan ikut sertanya bank lain untuk menguatkan atau mengkonfirm L/C tersebut. Apabila sebuah bank diminta bantuannya oleh bank pembuka untuk meneruskan L/C kepada Beneficitary dan menambahkan konfirmasinya, maka apabila bank yang pertama tersebut berbuat demikian, ia disebut juga sebagai Confirming Bank dan L/C yang bersangkutan menjadi Confirmed L/C. Pada Confirmed L/C terdapat dua bank yang menjamin pembayaran, yakni bank pembuka L/C itu sendiri dan Confirming Bank. Untuk mengkonfirm suatu L/C Confirming Bank biasanya memungut biaya yang disebut Confirming Commision sebesar presentase tertentu dari nilai $\mathrm{L} / \mathrm{C}$.

8. Beneficiary

Pihak bagi siapnya sebuah L/C diperuntukan atau pihak yang menerima jaminan pembayaran dari bank pembuka disebut Beneficiary.

Dengan menrima L/C, Beneficiary akan merasa terjamin bahwa pembayaran pasti akan dilakukan, karena pihak yang memberi jaminan itu adalah bank, yakni bank pembuka L/C.

\section{Jenis-jenis Letter of Credit:}

1. Revocable $\mathrm{L} / \mathrm{C}$

- Dapat ditarik kembali oleh importir secara sepihak

- Bagi eksportir mengandung resiko

2. Irrevocable $\mathrm{L} / \mathrm{C}$

- Tidak dapat ditarik kembali oleh importir secara sepihak

- Bagi eksportir dapat dijadikan jaminan

3. Irrevocable Confirmed $\mathrm{L} / \mathrm{C}$

- Tidak dapat ditarik kembali oleh importir secara sepihak

- Bagi eksportir dapat dijadikan jaminan

- Terlihat lebih "kuat" di mata eksportir karena di back-up oleh dua bank

- Biasanya diterbitkan oleh bank baru yang belum dikenal

- Jika eksportir meminta L/C jenis ini, biasanya importir terkena biaya tambahan, yaitu "confirmation fee" dari confirming bank.

4. Irrevocable Unconfirmed $\mathrm{L} / \mathrm{C}$

- Tidak dapat ditarik kembali oleh importir secara sepihak

- Bagi eksportir dapat dijadikan jaminan

- Biasanya diterbitkan oleh bank besar

5. Revolving $L / C$

- "Revolving": Nilai L/C di-"isi ulang" tapi di batasi oleh waktu. Jumlahnya dapat kumulatif, dapat juga non kumulatif

- Sifatnya dapat revocable / irrevocable

- Biasanya terdapat batas penarikan jumlah maksimal 
6. Red Clause L/C

- Jika importir ingin memberikan "panjar" kepada eksportir sebelum dokumen-dokumen dilengkapi

- Biasanya ditulis dengan tinta merah

- Sifatnya dapat revocable / irrevocable

7. Straight $\mathrm{L} / \mathrm{C}$

- Jatuh tempo hanya di negara bank pembuka L/C

- Sifatnya dapat revocable / irrevocable

8. Restricted $L / C$

- Pembayaran L/C hanya kepada bank yang namanya tercantum dalam L/C di negara Beneficiary

- Sifatnya dapat revocable / irrevocable

9. Negotiable L/C

- Dapat mengajukan wesel dan dokumen-dokumen L/C-nya ke bank mana yang dipilih oleh si eksportir

- Sifatnya dapat revocable / irrevocable

\section{Jangka waktu Letter of Credit:}

- $\quad$ Sight $L / C$

Mengandung syarat pembayaran berjangka "at sight" (segera dibayarkan pada saat ditunjukan atau diserahkan)

- $\quad$ Time L/C atau Term L/C atau Usance L/C

Mengandung syarat pembayaran berjangka "usance" (dibayarkan pada saat jatuh tempo)

\section{Posisi Bank Berhubungan dengan Letter of Credit, Ada 5 Yaitu:}

1. Issuing Bank (Opening Bank)

Sebagai bank pembuka L/C atas nama importir untuk eksportir

2. Negotiating Bank

Sebagai bank yang dapat menegoisasi L/C untuk eksportir

3. Confirming Bank

Sebagai bank yang menjamin pembayaran atas $\mathrm{L} / \mathrm{C}$

4. Paying Bank

Sebagai bank yang akan membayar L/C

5. Reimbursing Bank

Sebagai bank yang mengganti pembayaran L/C jika terjadi masalah pada Paying Bank dan Issuing Bank

Catatan: Posisi-posisi tersebut dapat saja "dirangkap" oleh suatu bank tertentu. 
Volume 2 Issue 1, April 2020

http://hk-publishing.id/ijd-demos

Gambar 1 Posisi Bank berhubungan dengan Letter of Credit

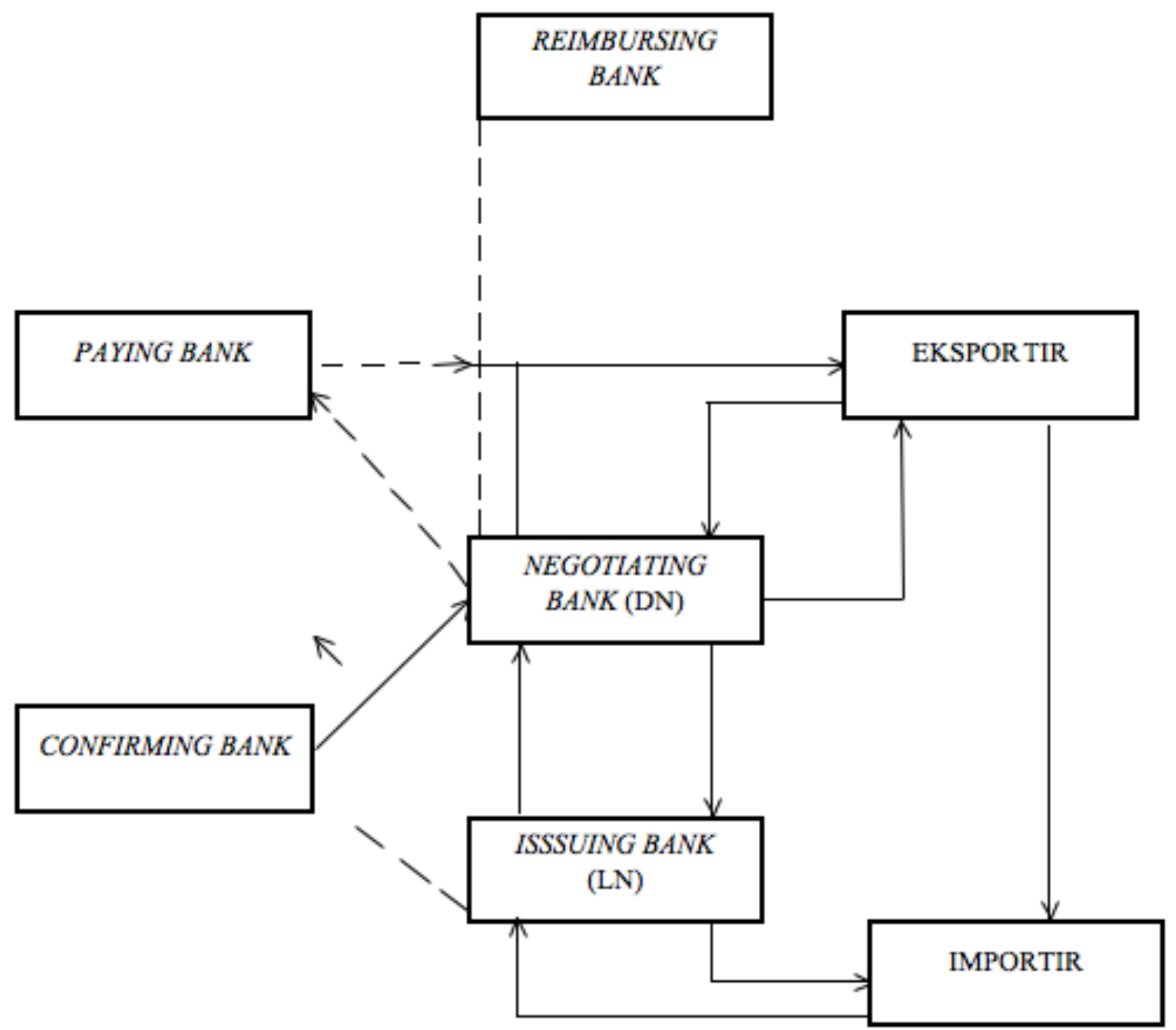

Sumberf:Materi Kuliah, Proses Perdagangan Internasional dan Asuransi

\section{Dokumen yang menyertai L/C}

Seperti kita ketahui bahwa L/C digunakan untuk membiayai dan menyelesaikan transaksi ekspor dan impor. Aspek lain dari transaksi tersebut yang sama pentingnya adalah dokumen yang diisyaratkan. Tanpa dokumen tersebut seorang eksportir ataupun importir tidak akan dapat memperoleh pembayaran dari sebuah bank yang menegoiser L/C terebut. Dokumen L/C tersebut adalah sebagai berikut:

\section{Commercial Invoice}

Adalah dokumen Invoice/faktur yang menyatakan tentang kondisi barang, nama dan alamat pembeli serta penjual, harga satuan, total harga dan uraian tentang barang, termasuk shipping marks-nya. 
Volume 2 Issue 1, April 2020

http://hk-publishing.id/ijd-demos

\section{Transport Documents :}

\section{- Air Way Bill}

Air Way Bill adalah dokumen pengangkutan barang yang diterbitkan oleh perusahaan angkutan udara, diterbitkan dalam rangkap tiga dan dicantumkan katakata "for carrier use only" (UCP 600 pasal 27).

\section{- Bill of Lading}

Bill of Lading adalah dokumen pengangkutan barang yang diterbitkan oleh perusahaan angkutan laut; diterbitkan dalam rangkap tiga da nada yang dapat dinegoisasikan dan juga yang Not-Negotiable (UCP 600 pasal 23-14).

- Freight Forwarder Receipt

Freight Forwarder Receipt adalah sertifikat tanda terima barang yang dikeluarkan oleh perusahaan forwarders.

\section{Draft/Bill of Exchange}

Adalah dokumen bukti kesanggupan membayar yang mempunyai kekuatan hukum, terdiri dari dua jenis yaitu:

- Draft/wesel diterbitkan oleh drawee yang menyatakan kesanggupan bayar.

- Promissory Note diterbitkan oleh bank dan merupakan surat kesanggupan bayar.

4. Other Documents :

- Certificate of Origin

Adalah dokumen yang menyatakan keaslian barang yang akan diekspor. Biasanya diterbitkan untuk barang-barang yang standard mutunya diawasi, dan diterbitkan oleh departemen yang ditunjuk untuk itu.

\section{- Certificate of Inspection}

Adalah surat pernyataan bahwa barang telah diperiksa sebelum dikapalkan, dikeluarkan oleh departemen yang independen.

\section{- Packing List}

Dokumen ini dibuat oleh eksportir yang menerangkan uraian dari barang-barang yang dipakai, dibungkus/diikat dalam peti dan sebagainya dan biasanya diperlukan oleh pejabat-pejabat bea cukai untuk memudahkan pemeriksaan seketika dan pemeriksaan mendalam atas isi dari suatu pengepakan termasuk uraian barangbarang tersebut, jenis bahan pembungkus/pengepak dan cara mengepaknya. Dengan adanya packing list dari setiap peti yang berisikan barang-barang tertentu maka importir atau pemeriksa barang tidak keliru untuk memastikan isinya, nama dan uraian barang tersebut haruslah sama dengan commercial invoice.

\section{Discrepancies / Penyimpangan didalam dokumen (UCP 600 Pasal 14)}

Didalam kasus tertentu didapat dokumen-dokumen yang tidak sesuai datanya, sehingga akan masuk dalam kategori dokumen yang menyimpang/tidak lengkap. Hal ini dapat digolongkan menjadi dua golongan, yaitu yang dapat diperbaiki (Minor Descrepancies) dan yang tidak dapat diperbaiki (Un Correctable Discrepancies).

Minor Discrepancies terjadi apabila ada kesalahan kecil dalam penulisan, misalnya kesalahan tanggal, keterangan salah dalam Invoice atau wesel. Eksportir dapat memperbaiki kesalahan ini dengan segera setelah menerima laporan penyimpangan. Un Correctable Discrepancies terjadi karena kesalahan dalam 
Volume 2 Issue 1, April 2020

http://hk-publishing.id/ijd-demos

pengiriman barang yang berbeda, keterlambatan pengiriman barang yang berbeda, keterlambatan pengiriman atau salah tujuan dan lain-lain.

Dalam kasus Discrepancies ini apabila diperbaiki harus melalui penyesuaian antara eksportir dan importir.

\section{Kesimpulan}

Berdasarkan hasil penelitian, penggunaan Letter of Credit $(L / C)$ didalam penyelesaian transaksi perdagangan luar negeri telah berjalan dengan baik, jenis Letter of Credit yang sering digunakan Irrevocaable Confirmed, dan jenis penggunaan oleh Beneficiary lain digunakan Tranferable L/C dengan waktu jatuh tempo L/C, Sight dan Usance didalam melakukan kegiatan perdagangan luar negerinya. Sedangkan dokumen yang menyertai L/C biasanya tergantung pada kesepakatan kedua belah pihak dan tercantum didalam L/C, tetapi secara garis besar dokumen yang menyertai L/C yaitu: Commersial Invoice, Packing List, Bill of Lading, Certificate of Origin, dan Draft/Bill of Exchange. Sedangkan faktor-faktor yang sering menjadi kendala dalam perdagangan luar negeri ini adalah: Biaya bank yang cukup besar (bank fee), discrepancies/ketidak sesuaian dokumen dengan barang ekspor, belum mempunyai kuota ekspor, kesulitan dalam mendapatkan bahan baku, barang telat dikirim karena barang yang dipesan tingkat kesulitannya tinggi. Sedangkan FaktorFaktor yang menjadi penghambat didalam penggunaan L/C untuk Impor yaitu: Biaya untuk membayar L/C belum tersedia (delay of payment), Uraian barang tidak sesuai dengan syarat-syarat dalam L/C dan purchase order (Discrepancies), Over Drawn, Pengapalan barang telat dari waktu yang telah ditentukan, karena adanya order susulan.

Ada beberapa saran yang mungkin bermanfaat ditinjau dari aspek praktisi, diantaranya: dalam pembuatan Sales Contract, seyogyanya pihak perusahaan lebih luwes dalam Term of Payment-nya, dimana Importir yang kredibilitasnya bagus, sebaiknya tidak selalu harus menggunakan Letter of Credit (L/C). sedangkan bagi Importir yang kurang kredibel, pihak perusahaan bisa menggunakan Irrevocable Confirmed L/C sebagai prinsip kehati-hatian. Departemen Ekspor-Impor merupakan departemen yang paling langsung berhubungan keluar perusahaan, dengan menyadari hal tersebut maka sudah sewajarnya sumber daya manusia harus bisa bernegoisasi dengan Supplier maupun Buyer dari luar negeri. Tentunya mereka harus bisa berbahasa asing (bahasa Inggris) dengan baik, lisan maupun tulisan maka sangat dianjurkan jika pegawainya harus memiliki nilai TOEFL minimal 500, karena akan sangat membantu didalam pencapaian target perusahaan. Pengetahuan tentang segala macam aturan didalam perdagangan internasional mutlak diperlukan bagi seluruh staff di bagian Exim, untuk hal itu perusahaan dianjurkan untuk memiliki koleksi buku yang berhubungan dengan perdagangan internasional dan sebisa mungkin disimpan dalam perpustakaan perusahaan. Didalam menjual produknya (Ekspor) kelengkapan dokumen L/C merupakan suatu syarat untuk dapat menarik wesel atas suatu L/C, oleh karena itu sebaiknya pihak perusahaan terlebih dahulu meneliti atau memeriksa kelengkapan dokumen-dokumen sehingga tidak akan terjadi penolakan penarikan wesel atas L/C tersebut dikarenakan dokumen L/C tidak lengkap (adanya discrepancies). Pemecahan untuk membayar 
L/C impor yang belum ada dananya biasanya dengan menggunakan Post Import Loan atau Trust Receipt.

\section{Referensi}

Amir MS, (1997) Seluk Beluk dan Tehnik Perdagangan Luar Negeri. PT. Pustaka Binaman Prasindo, Jakarta.

Amir MS, (1999) Letter of Credit. PT. Pustaka Binaman Pressindo, Jakarta.

AP Cowie, (1994) Oxford Advanced Learner's Dictionary. University Press, Oxford.

Balai Pustaka, (1995) Kamus Besar Bahasa Indonesia. Dep. Dik. Bud, Jakarta.

Barnas, Benny, et.al., (1996) Perdagangan Internasional. Dep. Dik. Bud, Bandung.

Budiarto, Teguh dan Ciptono, Fandy (1997) Pemasaran Internasional. BPFE, Yogyakarta.

F.J. Laug., Letter of Credit dan Cara Pembayaran dalam Perdagangan Internasional.

Hutabarat, Roselyne (1996) Transaksi Ekspor Impor. Erlangga, Jakarta.

Kotler, Philip (1996) Manajemen Pemasaran. PT. Prenhallindo, Jakarta.

Lumbantoruan, Magdalen (1992) Ensiklopedia Ekonomi Bisnis dan

Manajemen. PT. Cipta Adi Pustaka, Jakarta.

Moerjono, Agoes (1993) Melangkah Menuju Ekspor. Lembaga Pengembangan Perbankan Indonesia (LPPI), Jakarta.

R. Setiawan (1999) Pokok-pokok Hukum Perikatan. Putra A Bardin, Bandung.

Suparman, Agus (1999) Ketentuan Umum dan Prosedur Ekspor. Depperindo, Bandung.

Webster, Merriam (1993) Webster's New Internasional Dictionary. Massachusetts, USA

International Chamber of Commerce (2004) ICC Guide to Documentary Credit Operation for UCP-600 